\title{
Examination of the Relationships between Secondary School Students' Social Media Attitudes, School Climate Perceptions and Levels of Alienation
}

\author{
By Emrullah Deniz * \& Hilal Kazu
}

\begin{abstract}
The aim of this research is to examine the relationships between social media attitudes, school climate perceptions and level of alienation of students studying in secondary schools. In the 2018-2019 academic year, 418 students from various secondary schools in Mardin participated in the study. Descriptive statistics and structural equality model were used in the analysis of the data. As a result of the research, it was determined that the level of alienation variable is positively affected by sharing needs, social isolation and safe learning environment; the safe learning environment variable is negatively affected by the social competence variable while it is affected positively by the social isolation variable. Besides, the safe learning environment as a mediator resulted in negative effects between the need for sharing and alienation, positive ones between social isolation and alienation, negative ones between social competence and alienation, and finally negative effects between relationships with teachers and alienation. According to the results, it can be stated that creating a supportive school climate for students in educational settings will reduce students' tendency to use social media networks and prevent them from becoming alienated by making more friend.
\end{abstract}

Keywords: alienation, social media, school climate, structural equality model

\section{Introduction}

Today, rapid developments in the field of technology and the products produced related these developments have become more easily accessible thanks to the developed counties' economies. As technology products become an indispensable element of daily life, they bring along numerous changes in the lives and tendencies of society and individuals. The use of social media or social networks representing one of these changes has led to the emergence of new forms of relationships in the virtual world. Hatipoğlu $(2009$, p. 72$)$ states that social media networks provide an opportunity for the formation of communities that cannot be measured in virtual environments. Social media/social networks in particular have become new centers for teenagers (Boyd \& Ellison, 2008). Studies (Li, 2007; Lenhart, Purcell, Smith, \& Zickuhr, 2010) show that social media use is rapidly increasing especially among the 9-16 age group (school age group) due to the opportunities it provides to its users. It is known that different motivations such as content and information sharing, information acquisition, dialogue between

*PhD Student, Education Faculty, Institute of Education Sciences, Frrat University, Turkey.

${ }^{ \pm}$Associate Professor, Education Faculty, Institute of Education Sciences, Firat University, Turkey. 
small groups, and social support are among the goals of students using social media (Kaplan \& Haenlein, 2010, p. 61; Kim, Kim, Park, \& Rice, 2007; Tosun, 2010, p. 388).

\title{
Social Media
}

Social networks are defined as internet-based applications that allow their users to create a profile that other users can see and establish connections with other users (Ellison, Steinfield, \& Lampe, 2007). School life, which covers a large period of time in students' lives, and the interaction it involves, also create an opportunity for students to come together in virtual environments that they create through social media. Online social networks not only support the continuation of existing relationships but also prepare an environment for the establishment of new connections (Toprak, Yıldırım, Aygül, \& Binark, 2009, p. 29). In addition, the interaction between students in the virtual environment causes the formation of new forms of communication between their peers. On the other hand, the application and integration of technologies in education is seen as an integral part of successful school systems (Valdez, 2002). In addition to increasing interaction between students and teachers, the use of social media in educational settings offers a variety of opportunities as pedagogical tools (McLoughlin \& Lee, 2008, p. 69). These are listed as social support, collaborative information sharing and content creation. Just as students' social media usage trends stem from their personal choices, the school environment can also encourage this. Such that, negative interpersonal relationship styles, teacher behaviors, instructional dimensions and the continuity cycle created by them can directly or indirectly affect the tendency to use social media (Hoy, 2003; Loukas, Suzuki, \& Horton, 2006, p. 491).

The spread of social media use in the early years of education brings also a number of threats along with it. It is stated that as a result of the increase in the rate of participation in social networks of students in the younger age group, negative relationship styles develop in students (Amichai-Hamburger \& Hayat, 2011; Baker \& White, 2010; Van-Cleemput, 2010), academic success is negatively affected (Ryan, 2007), negative attitudes and perceptions develop (Balçıkanli, 2010), and analytical thinking skills are weakened (Sağlik, 2014). Apart from these, the alienation of students also emerges as an important threat.

\begin{abstract}
Alienation
The alienation may arise from multiple reasons such as academic success expectation, motivation, lack of feedback, limited academic programs, adolescent period characteristics, and peer relationships (Jacobs et al., 2002; Murdock, 1999; Russell, 1994). Schulz and Rubel (2011) define alienation as a process caused by the school environment, teacher attitudes, and social processes, which includes the academic and social alienation of students from schools. Similarly, Mackey (1974) states that the dynamics of alienation (anger, weakness, etc.) negatively affect learning in the educational environment and restrict social activities. Tezcan
\end{abstract}


(1997) states that one of the important factors affecting alienation is the relationships between students.

\section{School Climate}

The school environment, which includes components of the school climate and creates a strong communication network for students, aims to develop positive interactions between students and school employees in addition to offering opportunities that support the multi-faceted development (social, academic, etc.) of students. School climate is basically defined as a dynamic concept based on human relations, reflecting the collective behavior perceptions of individuals at school, developing in the process and affecting individuals and creating a continuous cycle between these elements (Ellis, 1988; Hoy, 2003).

Although the concept of school climate is used instead of educational organization, it is difficult to come across a common definition that experts agree on it. According to some researchers (Balc1, 2007), while school climate is seen as a process that reflects the school's learning and student success, another group of researchers (Bursalığlu, 2002; Hoy, 2003; Loukas, Suzuki, \& Horton, 2006, p. 491) define it as a set of characteristics which distinguish a school from others, based on interpersonal relationships, and which affect school members' behavior. School climate is also expressed as a concept that opens to the outside world and reflects the character of the school (Omay, 2008).

Describing the characteristics of the school climate, Welsh (2000) stated that the school climate is a determinant in the interaction between students, teachers and administrators, and contains unwritten elements such as beliefs, values and behavior patterns. On the other hand, Balc1 (2007) states that the interactional process between school members will be decisive in the behavioral patterns that will occur in the school environment and are based on common denominators. Although the definitions differ, there is a common emphasis that the school climate has an important effect on the attitudes and behaviors of its members.

\section{Relationships between Social Media, Alienation and School Climate}

Schools, which are an important learning area for students, besides improving students' academic, emotional, and behavioral skills; are also responsible for providing love for school, an atmosphere of trust, and a productive school climate (Arıman, 2007; Blum, 2005). The school climate basically has effects on individuals and on the efficiency of the school in general. Hoy, Tarter, \& Kottkamp (1991) stated that a learning environment in which teachers provide satisfaction has a positive effect on student success. In addition, Hoy, Tarter, \& Kottkamp (1991) states that healthy school climate is associated with high student achievement as well as a low level of alienation of students.

A supportive school environment will affect student achievements, participation in activities, and the development of instructional activities directly or indirectly by strengthening teachers' perceptions of competence (Bandura, 1997). The effects of school climate on students' socialization and self-realization cannot 
be denied. The fact that the school climate aims to be focused on student priorities, to support social activities, and to provide an environment of positive interaction between school employees has functions that prevent students from alienating from the school (Newmann, 1981; as cited in Polat, 2018). However, the widespread use of social media among students, in addition to increasing the interaction between students and teachers, as predicted by the healthy school climate, may lead to a decline in academic skills (Ryan, 2007), weakening of peer relationships (Russell, 1994), loneliness (Dean, 1961, pp. 753-754), and the alienation (Seeman 1959, pp. 275-276) stated above. In this context, social media, which have a permanent place in students' lives, and the power of interaction, appear as an important factor that directly and indirectly affects alienation from education in students.

\section{Literature Review}

Studies aiming to investigate indirect effects are considered to be important in terms of focusing on the dynamics of the relationships between these two variables. In the study conducted by Bilgin and Taş (2018), a positive relationship has been found between the safe learning environment, supportive teacher behaviors, and achievement-orientedness, which are among the dimensions of the school climate, and school engagement, but no relationship has been found between social media addiction and school engagement. Besides, in the aforementioned study, a negative relationship has been found between social media addiction and the safe learning subscale of the school climate.

When taking into consideration the results based on the relationship between the use of social network sites and loneliness, which reflects the social distance dimension of alienation, Doğan and Karakuş (2016) concluded in their study that loneliness predicts the use of social networks, and there is a significant relationship between loneliness and the use of social networks. According to the results of the research conducted by Al-Rahmi and Othman (2013) and Frein, Jones, and Gerow (2013), negative correlations were found between social media use and academic achievement.

In order to determine the effects of school climate on student attitudes and satisfaction, in the study conducted in Finland, Latvia, Norway, and Slovakia by Samdal, Nutbeam, Wold, and Kannas (1998), it was seen that the students in Latvia and Norway were more satisfied than the students in the other two countries. It was determined that the predictors of this situation were teachers' positive attitudes, their fairness, and students' feeling safe. In the research conducted by Argon and Çelik Y1lmaz (2016), a negative and low-level relationship has been found between the students' perception of peer relationships and their attitudes towards school. The results of the research conducted by Gürültiu and Deniz (2017) to examine the relationships between academic procrastination and social media use, which negatively affects academic achievement, revealed that students who use social media for a long time have higher academic procrastination behaviors. 
In the study conducted by Atalay (2014), it has been found that there is a positive relationship between the need for sharing and friend support, which is among the dimensions of social media, a negative relationship between social isolation and the relationship with teachers, and a positive relationship between teacher support and teacher relations. In the study conducted by Türkel and Dilmaç (2019) with 600 high school students, a positive and linear relationship was found between social media use and loneliness. Similarly, in the study conducted by Atik and Özer (2020) with 2291 high school students, it was determined that there is a negative relationship between alienation from school and trust in teachers, and between alienation from school and attitude towards school, and a positive relationship between academic achievement and attitude towards school. And again, Marcin, Morinaj, and Hascher (2020) have investigated the alienation in learning and its relation with the perception of the support provided by students' teachers and peers by analyzing the data obtained from 486 primary school and 550 secondary school students in Switzerland.

According to the results, the importance of supportive teacher attitudes in preventing students' alienation from learning at school is emphasized. As a result of the research conducted by Allen et al. (2014) with adolescents, it is argued that social networks create a paradox for social relationships. Social networks can create a source of alienation and exclusion, while facilitating individuals to form online groups. In the study conducted by Sappington (2020) with 442 undergraduates, preference for online social interaction, peer interaction, and social loneliness were significantly correlated. The results show that socially lonely individuals can use social media tools as a tool to meet their peer relationships.

\section{The Present Study}

It has been determined that studies on school alienation, attitudes towards social media, and school climate focus on variables such as academic achievement, peer interaction, student-teacher interaction, social media addiction, educational environment, and burnout. In addition to these studies, simultaneously examining the mediating role of school climate in the influence of secondary school students' attitudes towards social media on alienation will be useful in determining the complex relationships between variables (predictors). However, the data of this study, which consists of a cross-section between $5^{\text {th }}$ and $8^{\text {th }}$ grade, is expected to contribute positively to the clarification and development of theory and practices by contributing to studies that focus on high school and university students in the literature.

In this direction, the aim of this study is to examine the relationships between social media attitudes, school climate perceptions and alienation levels of students studying in secondary schools. However, it is thought that examining the relationships between the attitude towards social media and the school climate, between the attitude towards social media and the level of alienation, and between the school climate and alienation levels together will contribute to the literature in terms of both theoretical and practical aspects. With these thoughts, the hypotheses 
presented below and developed within the scope of the structural equation model (SEM) were determined. It is assumed that the model developed under SEM will fit well with the data while presenting the structure relationships. The hypotheses formulated for this purpose are presented below. It was investigated whether the relationships between the variables were positive or negative and directly or curvilinear with each other. As long as otherwise is not stated, all relationships were assumed to be statistically significant.

\section{Hypotheses}

1. It has been assumed that the increasing need for sharing (SN) in students will significantly predict supportive teacher behaviors (STB).

2. The level of social isolation (SI) is expected to be significantly affected by the STB.

3. The increase in social competence (SC) level is expected to predict STB significantly.

4. Relationship with teachers (RT) variable is expected to affect STB significantly.

5. It has been assumed that the $\mathrm{SN}$ will significantly affect the safe learning environment and positive peer interaction (SLEPI).

6. SLEPI is expected to be affected by SI significantly.

7. Higher SC observed in students is expected to affect the SLEPI variable significantly.

8. RT is expected to be associated with SLEPI significantly.

9. The level of alienation (SAL) will be significantly affected by the STB variable.

10. SLEPI and SAL variables are expected to be correlated significantly.

11. The SN level is expected to predict SAL significantly.

12. SI will affect $\mathrm{SAL}$ significantly.

13. SC is expected to affect SAL significantly.

14. SAL is expected to be associated with RT significantly.

15. It has been assumed that the STB will have a mediating effect between $\mathrm{SN}$ and SAL variables.

16. SI is expected to affect SAL significantly through the STB variable.

17. SAL is expected to be affected significantly by SC through STB.

18. It has been assumed that the STB will mediate the interaction between RT and SAL.

19. It has been assumed that the SN will explain the SAL through the SLEPI variable.

20. SLEPI is assumed to be a variable that will affect the interaction between SI and the SAL.

21. It has been assumed that SAL will be affected significantly by SC through SLEPI.

22. RT is expected to affect SAL significantly through SLEPI. 
Relationships hypothesized depending on this purpose are presented on Figure 1.

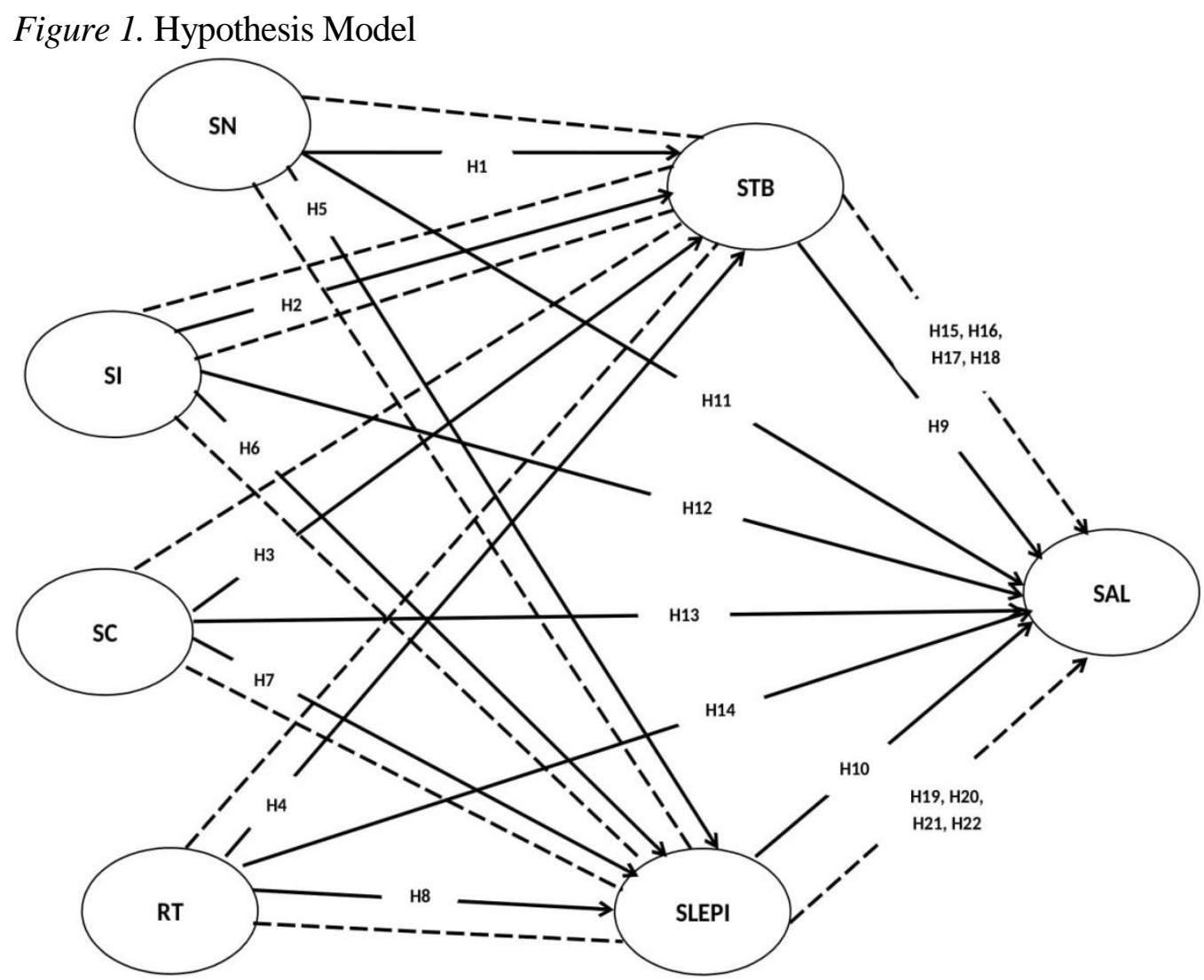

- . . Indirect Effects

Direct Effects

Note: Arrows represent aspects of relationship. Symbols consisting of the letter " $\mathrm{H}$ " and numbers (for example H1) represent the hypothesis relationship and number between variables. Dotted lines represent indirect effects, while straight lines represent direct effects.

\section{Methodology}

\section{Research Model}

Since this research is based on examining the relationships between two or more variables, it is a correlational study. 


\section{Participants}

The population of the research was formed by the students studying in official secondary schools in Artuklu district of Mardin province in the 2018-2019 academic year. In determining the sample size, a table of sample sizes created from different population sizes was used. In the direction of the related table, it was determined that 370 students could represent the population of 17,000 students with a reliability coefficient of 0.05 and a sampling error of $5 \%$ (Yazıcıoğlu \& Erdoğan, 2004, p. 50). This study was conducted on the sample selected from the research population with the method of disproportionate cluster sampling. According to Karasar (2005, p. 114), disproportionate cluster sampling is the sampling in which all clusters for similar purposes in the population have an equal chance of being selected. Accordingly, the sample of the study consists of students studying in 3 public secondary schools. In the schools selected for sampling, the classes to be attended according to grade levels were determined by simple random sampling method. Simple random sampling is the condition in which every element in the population has equal chances to enter the sampling (Arikan, 2004, p. 141). Due to possible problems in the application of the scales, they were distributed to 470 students during the implementation phase and 418 of these scales were included in the analysis. The distribution of students by grade level and gender is presented in Table 1.

Table 1. Distribution of Students by Class and Gender

\begin{tabular}{|l|c|c|c|c|}
\hline \multirow{2}{*}{ Grades } & \multicolumn{2}{|c|}{ Female } & \multicolumn{2}{c|}{ Male } \\
\cline { 2 - 5 } & $\mathrm{f}$ & $\%$ & $\mathrm{f}$ & $\%$ \\
\hline $\mathbf{5}^{\text {th }}$ grade & 59 & 52.2 & 54 & 47.8 \\
\hline $\mathbf{6}^{\text {th }}$ grade & 51 & 51.5 & 48 & 48.5 \\
\hline $7^{\text {th }}$ grade & 60 & 55.0 & 49 & 45.0 \\
\hline $\mathbf{8}^{\text {th }}$ grade & 55 & 56.7 & 42 & 43.3 \\
\hline Total & 225 & 53.8 & 193 & 46.2 \\
\hline
\end{tabular}

When Table 1 is examined, it is seen that $27 \%(\mathrm{n}=113)$ of the students participating in the research are $5^{\text {th }}$ grade, $23.7 \%(n=99)$ are $6^{\text {th }}$ grade, $26 \%$ $(n=109)$ are $7^{\text {th }}$ grade and $23.2 \%(n=97)$ are $8^{\text {th }}$ grade students. Of the total number of students participating in the study (418), $53.8 \%$ are female and $46.2 \%$ are male.

\section{Data Collection Tools}

To collect data on the variables determined within the scope of the study, the Social Media Attitude Scale, School Climate Scale, Student Alienation Scale and Personal Information Form developed by the researchers have been used.

Social Media Attitude Scale. Social Media Attitude Scale (SMAS) was developed by Otrar and Argin (2015) for secondary school and high school students between the ages of 13-18. The scale consists of 4 factors with a total of 23 items. These are social competence (SC), sharing need (SN), relationship with teachers (RT), and social isolation (SI). Within the scope of the construct validity 
of the scale, it was tried to determine whether the previously determined factors, especially the subscales, continued throughout this study or not. For this purpose, exploratory (EFA) and confirmatory (CFA) factor analyses were applied. As a result of EFA, it was determined that all items were loaded on relevant factors determined in the original scale; it has been observed that only one item (item 18) produces an overlapping value. Since the overlapping item was above the tolerance value $(0.10)$ between the factor loadings, by keeping it out of analysis the analysis was repeated (Çokluk, Şekercioğlu, \& Büyüköztürk, 2018). As a result of EFA, the factor loading value ranges for the scale sub-dimensions varied between 0.5240.660 for the first factor, $0.529-0.734$ for the second factor, $0.488-0.644$ for the third factor and $0.482-0.858$ for the fourth factor, and they were seen to represent $55.41 \%$ of total variance. CFA was applied to verify the scale and fit index values were checked. It was seen that the results met the minimum fit indices $\left(\mathrm{X}^{2} / d f=2.15\right.$, RMSEA=0.053, CFI=0.928 and SRMR=0.053) recommended by Kline (2019). The Cronbach alpha coefficients calculated for scale reliability are: $\mathrm{SN}=0.86$, $\mathrm{SI}=0.82, \mathrm{SC}=0.80$ and $\mathrm{RT}=0.73$. Considering these data, it can be said that the coefficients are quite reliable and in a high reliability interval (Özdamar, 2016).

School Climate Scale. The School Climate Scale (SCS), developed by Çalık and Kurt (2010) for secondary school students, consists of 22 items and three factors. These factors are listed as supportive teacher behaviors (STB), achievement orientation (AO), and safe learning environment and positive peer interaction (SLEPI). As a result of EFA applied for structural validity, AO and STB subscales were combined under a single factor unlike the original scale, item 9 was eliminated since it produced overlapping values, and a total two-factor structure was obtained. It was determined that the factor loading values of the scale subdimensions varied between $0.385-0.682$ for the STB and $0.358-0.620$ for the second factor and $40.17 \%$ of the total variance was explained. When the items related to AO (for example, item 10: Our teachers expect us to be successful) are examined, it can be said that they are within the scope of supportive teacher behaviors (STB), as determined in the study of Hoy, Tarter, and Kottkamp (1991) on evaluating school climate. Results for CFA $\left(\mathrm{X}^{2} / d f=2.28\right.$, RMSEA $=0.055$, $\mathrm{CFI}=0.905$ and $\mathrm{SRMR}=0.054$ ) met the relevant cut-off values. Cronbach's alpha coefficients for scale reliability have been calculated as 0.87 and 0.76 , respectively.

Student Alienation Scale. The Student Alienation Scale (SAS), developed by Sanberk (2003) for high school students consists of 17 items and four subdimensions. The sub-dimensions are listed as powerlessness, meaninglessness, irregularity and social distance. As a result of the EFA applied, it was determined that all items were loaded on the relevant factors determined in the original scale; however, 2 items (4 and 12) were excluded from the analysis because they produced overlapping values. These two items belong to the social distance subscale, which consists of three items in total. The fact that the factor decreasing to a single item (item 8) after the related items are eliminated, does not comply with the suggestion that the factors should consist of at least three items (Byrne, 2010, p. 13). Therefore, factor analysis limited by three factors was repeated. 
According to the results, the scale consisted of weakness, irregularity and meaninglessness subscales, and the 8th item (I will be happy when I do not have to go to school) got loaded on the irregularity subscale. It was determined that the factor loading values for the scale sub-dimensions varied between $0.355-0.560$, 0.404-0.674 and 0.328-0.835, respectively. According to the CFA results $\left(\mathrm{X}^{2} / d f=1.62, \mathrm{RMSEA}=0.047, \mathrm{CFI}=0.961\right.$ and $\left.\mathrm{SRMR}=0.047\right)$, it can be said that the data are compatible with the model. The Cronbach alpha results for the reliability analysis are as follows: $0.60,0.78$, and 0.74 , respectively. In this study, the total frequency score of SAL was used.

\section{Data Collection}

The distribution of measurement tools used to collect research data was carried out after necessary permission was obtained from the Mardin Provincial Directorate of National Education. The relevant schools were visited by one of the researchers, and the students were informed about the purpose of the research, its duration, the content of the scales and the confidentiality of the data. It has been reported that answering the scales is on a voluntary basis and it is not necessary to provide identifiable information for individuals. Written consent was obtained from the students and those who did not want to participate in the research were excluded from the research. Students received no incentives in return for their participation in the research. The study was approved by the ethics committee of the institute of educational sciences of Frrat University.

\section{Analysis of the Data}

SPSS 22 and AMOS 24 software were used to analyze the data obtained within the scope of the research. SPSS was used for item analysis and other analyzes, and AMOS was used for CFA and structural equation model (SEM). CFA, which is within the scope of SEM, is used to examine the compatibility of the measurement tool developed based on a theory with data (Tabachnick \& Fidell, 2015). SEM, on the other hand, is the general name of techniques that allow the investigation of latent structures through observed variables (Jöreskog \& Sörbom, 1993). It is possible to test a theoretical model through SEM based on causal relationships between observed variables (Schumacker \& Lomax, 2010, p. 2). Therefore, SEM enables the complex relationships in theoretical tests to be understood by using scientific hypothesis testing method. In SEM applications, there are elements such as latent variable, measurement errors in dependent and independent variables, multiple indicators, mutual causality, concurrency and interdependence (Çokluk et al., 2018, p. 253). Before starting the analysis, the assumptions required by SEM, which is one of the multivariate statistical methods, should be examined. Tabachnick and Fidell (2015) and Çokluk et al. (2018, pp. 11-35) emphasize that the assumptions like missing values, extreme values, sample size, normality, linearity, multicollinearity and singularity should be tested. After the frequency (13 missing data) and distribution (random) of missing values were examined, values reflecting the mean of the series were assigned to replace 
the missing data, suggested by Tabachnick and Fidell (2015). In the control of the extreme values of the variables in the data set, it is stated that the values above +3 and below -3 should be excluded from the analysis by examining the $\mathrm{Z}$ scores of the data (Johnson \& Wichern, 2007). In this context, by examining $\mathrm{Z}$ scores, no values were found above +3 and below -3 . Additionally, Mahalanobis distance was calculated in multiple data, and no extreme values were found either. In SEM analyzes, it is stated that a sample size greater than 300 will yield good results (Tabachnick \& Fidell, 2015); however, it is stated that acceptable results can also be obtained from samples of 200 or more (Kline, 2019). The sample size reached within the scope of the research is 418 people. Therefore, it can be said that the size of the data is suitable for SEM analyzes. Just like Tabachnick and Fidell (2015) stated, it was paid attention that the skewness and kurtosis values were at the significance level of $\mathrm{p}=0.05$ and were between +1.96 and -1.96 . Multivariate linearity was checked by examining scatter diagrams between variables and p-plot charts, and it was assumed that the data set provided multivariate normality.

\section{Results}

\section{Structural Model Findings}

In the study, descriptive statistics related to the model variables were included first, and then the findings of the mediation model, which is based on the measurement model created with the latent variables and their indicators in the model and the multi-group analysis, and aiming to determine the indirect and direct effects are shared.

Descriptive Statistics for Model Variables. Descriptive statistics and twovariable correlation coefficients for all study variables included in the established model are given in Table 2.

Table 2. Descriptive Statistics and Correlation Coefficients for the Model

\begin{tabular}{|l|c|c|c|c|c|c|c|c|c|c|c|}
\hline $\begin{array}{l}\text { Model } \\
\text { Variables }\end{array}$ & $\mathbf{1}$ & $\mathbf{2}$ & $\mathbf{3}$ & $\mathbf{4}$ & $\mathbf{5}$ & $\mathbf{6}$ & $\mathbf{7}$ & $\mathbf{M}$ & SD & Skew. & Kurt. \\
\hline $\mathbf{1 . S T B}$ & 1.00 & & & & & & & 3.40 & 0.870 & -0.280 & -0.509 \\
\hline 2. SLEPI & $-0.379^{* *}$ & 1.00 & & & & & & 3.03 & 0.977 & 0.023 & -0.800 \\
\hline 3. SC & 0.094 & $-0.159^{* *}$ & 1.00 & & & & & 2.36 & 1.08 & 0.525 & -0.722 \\
\hline 4. SN & 0.045 & $-0.117^{*}$ & $0.645^{* * *}$ & 1.00 & & & & 3.16 & 1.14 & -0.200 & -0.988 \\
\hline 5. RT & 0.074 & -0.066 & $0.404^{* *}$ & $0.527^{* *}$ & 1.00 & & & 2.74 & 1.35 & 0.167 & -1.251 \\
\hline 6. SI & -0.070 & $0.129^{* * *}$ & -0.075 & -0.020 & 0.033 & 1.00 & & 3.42 & 1.18 & -0.369 & -0.914 \\
\hline 7.SAL & -0.060 & $0.111^{*}$ & -0.038 & 0.066 & 0.020 & $0.136^{* *}$ & 1.00 & 2.53 & 0.753 & 0.447 & -0.248 \\
\hline
\end{tabular}

Note: $* p<0.05 . * * p<0.01$.

In Table 2, the measurement ranges, mean, standard deviation, and kurtosisskewness values of the variables in the measurement model are included. As stated above, the kurtosis-skewness values obtained to test univariate normality reveal that the distribution does not deviate excessively from normality. Pearson correlations were not found to have very high correlation values ( 0.9 and above; - 
0.9 and below) between the variables. Therefore, it can be said that multiple connectivities and singularity assumptions are provided.

Findings related to the Measurement Model. The path diagram with standardized estimates of SEM and fit indexes for the model are presented in Figure 2.

Figure 2. Structural Equality Model

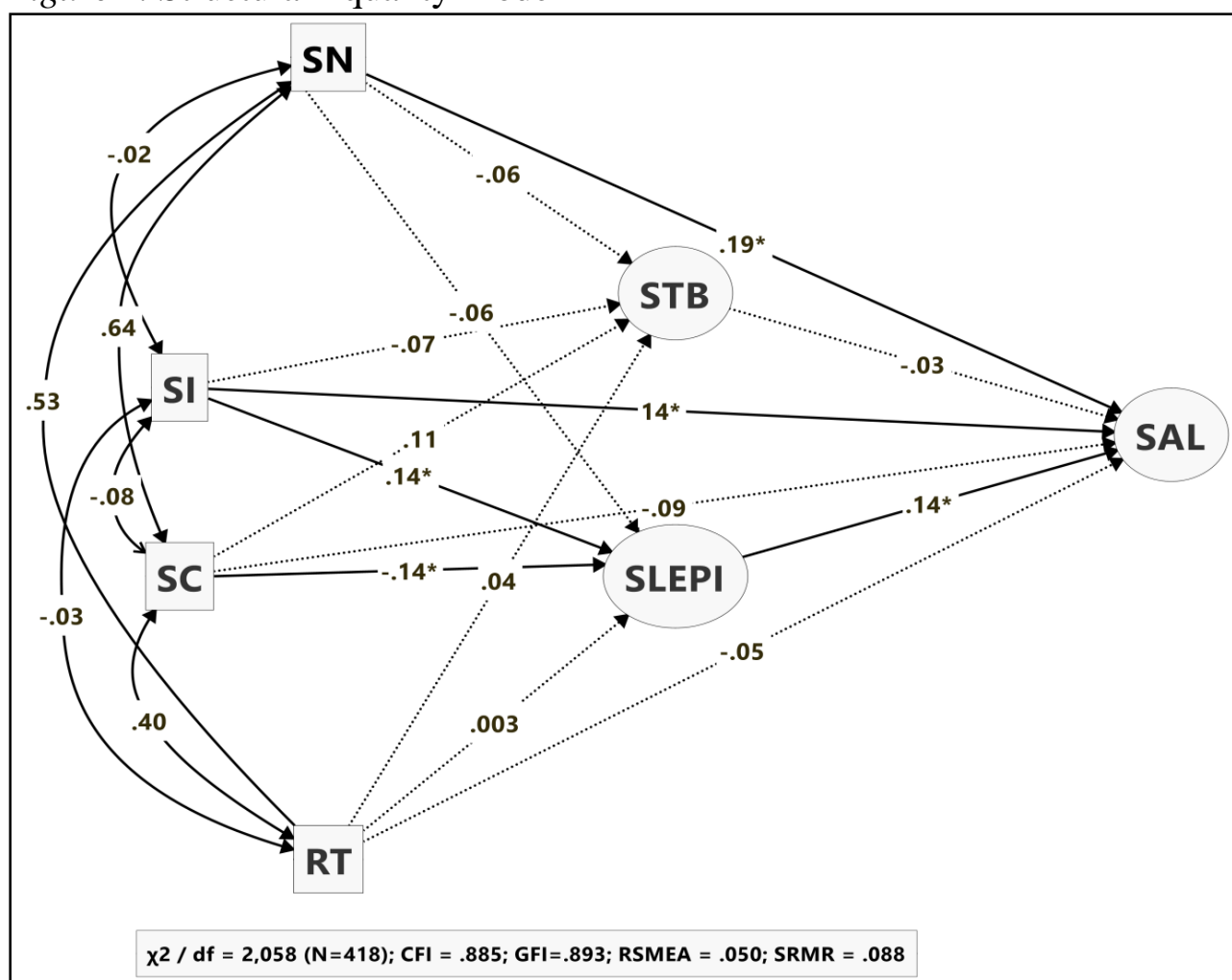

Note: $* p<0.05$.

In the SEM diagram presented in Figure 2, dotted lines represent insignificant and straight lines represent meaningful relationships. To develop the hypothetical model, the maximum likelihood (MLR) estimation was used together with a bootstrapping procedure. When looking at the direction of effects and factor loadings between implicit variables, it is seen that the variables SC and SLEPI $(\beta=-0.13, p<0.05)$ are significantly and negatively related to each other, SI and SLEPI $(\beta=0.13, p<0.05)$, SN and SAL $(\beta=0.19, p<0.05)$, SI and SAL $(\beta=0.14$, $p<0.05)$, and finally, the variables SLEPI and SAL $(\beta=0.14, p<0.05)$ are significantly and positively related to each other. The fit indices of the model have been examined and interpreted, according to Byrne (2010) and Kline (2019) guidelines, using the criteria in Table 3. 
Table 3. Ranges for SEM Fit Indexes

\begin{tabular}{|l|c|c|c|c|}
\hline $\begin{array}{l}\text { Overall Fit } \\
\text { Indices }\end{array}$ & Acceptable fit Ranges & Good Fit Ranges & Value & Comment \\
\hline$\chi \mathbf{2} / \boldsymbol{d} \boldsymbol{f}$ & $3 \leq \chi 2 / d f \leq 5$ & $0<\chi 2 / d f \leq 3$ & 2.058 & Good Fit \\
\hline RMSEA & $0.05 \leq \mathrm{RMSEA} \leq 0.10$ & $0 \leq \mathrm{RMSEA} \leq 0.05$ & 0.050 & Good Fit \\
\hline CFI & $0.90 \leq \mathrm{CFI} \leq 0.95$ & $0.95 \leq \mathrm{CFI} \leq 1$ & 0.885 & Acceptable Fit \\
\hline GFI & $0.85 \leq \mathrm{GFI} \leq 0.90$ & $0.90 \leq \mathrm{GFI} \leq 1$ & 0.893 & Acceptable Fit \\
\hline SRMR & $0.05 \leq \mathrm{SRMR} \leq 0.10$ & $0 \leq \mathrm{SRMR} \leq 0.05$ & 0.088 & Acceptable Fit \\
\hline
\end{tabular}

When the model fit values in Table 3 are examined, it can be said that the model established is sufficiently compatible with the data; however, the harmony of the model as a whole necessitated a review of the MIs (modification indices). Brown (2006) proposes to include the additional covariance between the two indicators in the analysis using error covariance within a one-dimensional structure, instead of adding another latent factor. After reviewing MIs by following the procedures determined by Byrne (2010, p. 89), parameter change statistics related to error covariances revealed significant values (see Annex 1). For example, the change parameter coefficients for the error covariances of the STB factor (e32e33, e36-e37) were respectively calculated as 0.371 and 0.404 . The parameter variation coefficient of the SLEPI factor (e38-e39) was calculated as 0.532. The model obtained as a result of post hoc analysis revealed a statistically significant difference at the level of $\Delta_{X^{2}}=81.654$ compared to the previous model. These covariances, added as a result of post hoc analyses, indicate that there is a content conflict. The significance levels of the standardized path coefficients, standard error coefficients, and path coefficients of SEM are presented in Table 4.

Table 4. Hypothesis Test Results in Structural Model

\begin{tabular}{|c|c|c|c|c|c|c|}
\hline Hypothesis & Model Parameters & $\boldsymbol{\beta}$ & SE & $\begin{array}{c}P \\
\text { Value }\end{array}$ & Result & $R^{2}$ \\
\hline H1 & SN----->>STB & -0.060 & 0.055 & 0.432 & Not Supported & \multirow{4}{*}{0.016} \\
\hline $\mathrm{H} 2$ & SI------->STB & -0.072 & 0.038 & 0.224 & Not Supported & \\
\hline H3 & SC------>STB & 0.112 & 0.054 & 0.104 & Not Supported & \\
\hline H4 & RT----->STB & 0.049 & 0.039 & 0.437 & Not Supported & \\
\hline H5 & SN ----->SLEPI & -0.065 & 0.049 & 0.384 & Not Supported & \multirow{4}{*}{0.053} \\
\hline H6 & SI------->SLEPI & 0.145 & 0.035 & $0.016^{*}$ & Supported & \\
\hline H7 & SC------>SLEPI & -0.139 & 0.049 & $0.050 *$ & Supported & \\
\hline H8 & RT------>SLEPI & 0.003 & 0.034 & 0.907 & Not Supported & \\
\hline H9 & STB---->SAL & -0.027 & 0.041 & 0.656 & Not Supported & \multirow{6}{*}{0.064} \\
\hline H10 & SLEPI-->SAL & 0.138 & 0.055 & $0.050 *$ & Supported & \\
\hline H11 & SN ------>SAL & 0.190 & 0.042 & $0.033^{*}$ & Supported & \\
\hline H12 & SI-------->SAL & 0.138 & 0.029 & $0.030 *$ & Supported & \\
\hline H13 & SC------->SAL & -0.088 & 0.040 & 0.279 & Not Supported & \\
\hline H14 & RT------->SAL & -0.050 & 0.028 & 0.480 & Not Supported & \\
\hline
\end{tabular}

Note: $* p<0.05$.

According to the results of the SEM analysis in Table 4, 5 of the 14 hypotheses (H6, H7, H10, H11, and H12) created according to the sub-problems of the research were supported. As a result of the analysis, it was found that; STB is 
predicted by the variables SN, SI, SC, and RT at the level of $R^{2}=0.016$, SLEPI is predicted at the level of $R^{2}=0.053$ by those variables, and finally SAL is predicted as $R^{2}=0.064$ by STB, SLEPI, SN, SI, SC, and RT variables.

Findings regarding the Mediation Model. SEM provides the opportunity to determine the direct and indirect effects of variables by performing multi-group analyzes. The confirmatory framework determined to test the hypotheses consists of testing the conformity of the assumed model to the real data and rejecting the model without modification in case of suitability shortage (Byrne, 2010). The default model was tested using a maximum probability estimate with a bootstrapping procedure (5,000 iterations, predictor bias-corrected confidence intervals of 95\%; Preacher \& Hayes, 2008). Performing such an analysis instead of separate mediation analyzes allows directly testing the hypothesis that there is no difference between total effect and direct effect (Preacher \& Hayes, 2004). Besides, such an analysis reduces the probability of Type I error, which is concluding that it exists even though there is no mediator (Preacher \& Hayes, 2008). Just like previously mentioned, mediation testing was run using the bootstrapping procedure, which consists of generating many new samples based on the general population. The results of the bootstrapping analysis show that 3 (H19, H21 and H22) of the 8 (H15, H16, H17, H18, H19, H20, H21 and H22) hypotheses, which are the continuation of the sub-problems of the research, have been supported (Table 5).

Table 5. Bootstrapping Analysis Results related to Indirect Effects between Variables

\begin{tabular}{|l|l|c|c|c|c|c|}
\hline Hypothesis & Model Parameters & Indirect Effect & Direct Effect & SE & $\begin{array}{c}\text { P } \\
\text { Value }\end{array}$ & Result \\
\hline H15 & SN---STB---->SAL & -0.003 & 0.082 & 0.007 & 0.266 & Not Supported \\
\hline H16 & SI---STB ---> SAL & 0.006 & 0.156 & 0.008 & 0.180 & Not Supported \\
\hline H17 & SC---STB ---> SAL & -0.009 & -0.015 & 0.009 & 0.147 & Not Supported \\
\hline H18 & RT-- STB ---> SAL & -0.006 & 0.007 & 0.007 & 0.175 & Not Supported \\
\hline H19 & SN---SLEPI-> SAL & -0.024 & -0.104 & 0.016 & $0.019^{*}$ & Supported \\
\hline H20 & SI--- SLEPI -> SAL & 0.020 & 0.144 & 0.015 & $0.048^{*}$ & Supported \\
\hline H21 & SC-- SLEPI -> SAL & -0.028 & 0.004 & 0.018 & $0.032^{*}$ & Supported \\
\hline H22 & RT-- SLEPI -> SAL & -0.013 & 0.012 & 0.012 & $0.050^{*}$ & Supported \\
\hline
\end{tabular}

Note: $* p<0.05$.

It can be understood from Table 5, the indirect effects of the hypotheses H19, $\mathrm{H} 20, \mathrm{H} 21$, and $\mathrm{H} 22$ were found to be statistically significant. In the related table, it was determined that the total effect value of the SN on SAL was $\beta=0.079$, the direct effect value was $\beta=0.082$, and the $\beta=-0.003$ unit difference between them was caused by negative indirect SN effects on SAL occurring through SLEPI. This situation can be interpreted that when a safe learning environment with peer interaction increases, the need for sharing reduces the effect on student alienation levels. Similarly, this situation reduced the relationship between SLEPI, SC, and SAL indirectly at the level of $\beta=-0.028$ and negatively. In addition, the indirect effect through SLEPI contributed $\beta=0.020$ units to the direct effect between SI and SAL levels $(\beta=0.144)$, resulting in a total effect value of $\beta=0.163$ units. According 
to this result, it was determined that there is a positive relationship between SI and SAL levels. In other words, as the social isolation levels of the participants in the study increased, their level of alienation did so; inclusion of the intermediary variable SLEPI in the analysis contributed to the further increase of this level. Finally, the SLEPI has resulted in obtaining a total effect value of $=0.000$ by making a negative contribution of $\beta=-0.013$ units to the positive effect between RT and SAL at the level of $\beta=0.012$. According to the $\mathrm{H} 22$ hypothesis, it can be said that alienation will also decrease through a safe learning environment and peer interaction, along with healthy relationships with teachers.

\section{Discussion}

With the widespread use of social media among students, the way of communication has also begun to change, and social media has become one of the most preferred communication tools. It is noted that the use of social media, which affects large masses, is a part of people's daily lives (Boyd \& Ellison, 2008). It is stated that the increasing rate of social media usage brings about significant changes in people's lives along with the negligence of important functions of life (Andreassen, Pallesen \& Griffiths, 2017). In this context, the determinants of individuals' behaviors and their effects have been focused on in this study, which focuses on the relationships between social media, school climate, and alienation variables.

As a result of SEM analysis, it was found that social isolation and social competence have significant effects on a safe learning environment and peer interaction. School climate reflects people's school experiences, norms, goals, values, interpersonal relationships, practices and organizations, and relationships with teachers (Thapa \& Cohen, 2013). Hoy (2003) points out that non-supportive school environments and negative student-teacher interactions increase students' tendency to use social media. When H6 and H7 hypothesis are taken into account, it is expected that as social isolation increases, the need for a safe learning environment and peer interaction increases, and as social competence increases, the need for a safe learning environment and peer interaction decrease.

The rates of students' use of social media tools and the loneliness and social isolation that develop accordingly are closely related to safe learning environments and friendship relations. For instance, the hypotheses H9, H13, and H14 have shown that supportive teacher behaviors, social competence, and relationship dimensions with teachers affect alienation negatively, even if they have not achieved statistical significance in the structural model. In this sense, integrating social media tools into educational practices and applying an interactive process involving teachers will help students reduce the feeling of loneliness and develop a positive attitude towards teachers. As a matter of fact, the hypothesis $\mathrm{H} 8$, too, which is an unsupported hypothesis in the structural model, reflected the positive relationship between a relationship with teachers, and a safe learning environment, and peer interaction. 
Supporting the hypotheses H6 and H7 results, Öztürk and Talas (2015) have stated that the use of social networks, which have become widespread among students, in educational environments would increase the interaction between students and teachers and increase the opportunities for students to get to know each other. Similarly, Goel and Singh (2016) concluded in their study that social media tools affect the academic success of institutions positively apart from the need for sharing by helping the development of positive attitudes towards project preparation, homework, and other academic activities. It has been suggested that the use of social networks not only increases social competence and interaction, but also supports active learning and peer collaboration (Ajjan \& Hartshorne, 2008). Therefore, it can be said that the creation of a supportive school climate and encouragement of positive teacher attitudes in educational environments will promote students to use social media networks for academic purposes together with their sharing needs; and so this will reduce their social isolation level and support them to make more friendships. This result shows that the hypotheses H6 and $\mathrm{H} 7$ are compatible with the literature and related studies.

The levels of sharing need and social isolation of students had significant effects on their alienation (H11 and H12). According to the results of the SEM analysis of the model established in the research, the strongest relationship that emerged is between the need for sharing and alienation $(\beta=0.19)$ (Table 4, Figure 2). Alienation is defined as a process that includes distancing of students from a school academically and socially because of the school environment, teacher attitudes, and social processes (Schulz \& Rubel, 2011). Alienation is also defined as the gradual alienation of students from learning activities and learning processes (Sidorkin, 2004). Mackey (1974) states that elements such as powerlessness and social distance that affect the process of alienation negatively affect the learning process in educational settings and restrict social activities. In fact, it has been proven by research that alienating from school is an important determinant of participation in educational activities and educational success (Hadjar, Backes \& Gysin, 2015; Safipour, Tessma, Higginbottom, \& Emami, 2010).

As can be seen from the explanations, alienation sets the stage for the abstraction of students from educational environments and learning processes. In this context, it can be argued that social media, which is used as a communication tool, can affect students' alienation from education by playing an active role in this process. In other words, it can be expected that the level of alienation will also increase if the need for sharing and the level of social isolation increases in students. Supporting this result of the study, Atalay (2014) found that positive friend and teacher support has a negative effect on the need for sharing and social isolation as a result of his research. Similarly, according to the results of the research conducted by Mutlu (2014), Ceyhan and Ceyhan (2008) and Kim, Kim, Park, and Rice (2007) it is stated that the level of loneliness affects the tendency towards social networks, therefore, having more or fewer friendship relationships in the virtual environment can trigger social isolation. When the research findings of Savc1 and Aysan (2018) are examined it is seen that loneliness increased the use of social media, in other words, loneliness and social media use were positively related to each other. Young, Pistner, O'mara, and Buchanan (1999) states that 
students' school adaptation and attitudes towards school are negatively affected by social media and cyber relationship addictions. Thus, it can be said that the use of social media can affect student life in various ways and that a supportive school environment and positive peer relationships can play an important role in this process. In this context, it can be concluded that the hypotheses $\mathrm{H} 11$ and $\mathrm{H} 12$ are compatible with the relevant literature and research results.

It is argued that the need for sharing and social isolation, like Finn (1989) stated, will decrease with the effect of providing a safe learning environment and peer interaction and the positive school perception that will occur accordingly, so then the level of alienation will decrease. However, with the decrease of alienation from the school, it can be expected that students' educational output and school participation levels will increase positively. However, with the decrease of alienation from the school, students' educational output and school participation levels can be expected to increase positively. On the other hand, it was found that the rejected $\mathrm{H} 1, \mathrm{H} 2, \mathrm{H} 3$, and $\mathrm{H} 4$ hypotheses in the structural model showed that none of the sub-structures of social media predicted the supportive teacher behaviors, which are the sub-structures of the school climate scale, and the indirect effects of the H15, H16, H17, and H18 hypotheses did not reach statistical significance. According to this result, it is revealed that the causal connections based on the relationships between the school climate components and other variables should be studied comprehensively, especially what effects supportive teacher behaviors can promote when mediating between social media use and alienation.

Another statistically significant result obtained in this study is that the positive effect (H10) of SLEPI on SAL is unexpectedly contrary to the existing literature and research results (Atik \& Özer, 2020). This result can be explained by the fact that the relationships between a safe learning environment and peer support and alienation are linked to different factors (e.g., self-efficacy) and are complex issues that can be affected by various social agents. However, it may be necessary to remeasure with a new index by reviewing the existing criteria for measuring the theory-supported concepts that constitute the problem of this study.

According to another statistically significant result obtained from the SEM analysis (H19, H21, and H22), it has been determined that SLEPI has a negative mediating effect on the alienation of SN, SC, and RT. In other words, it has been determined that SLEPI reduces alienation by affecting the direct effect of SN, SC, and RT on alienation indirectly. These findings proved that the positive correlations between social isolation-alienation and social network use, which were revealed by previous studies (Ingvadóttir, 2014; Kang, 2007; Kraut, Kiesler, \& Scherlis, 1998; Türk \& Kazan, 2019; Yavuz, 2017), regressed through the SLEPI. In his research examining students' use of social media in terms of various variables, Kang (2007) concluded that social network use leads students to loneliness, disorder, and even depression. In the same study, it is stated that social support will contribute positively to the reduction of loneliness and accompanying depressive feelings in students. Al-Kandari and Al-Sejari (2020) concluded in their study on a sample of 1431 Kuwaiti residents between the ages of 17-26, that social isolation leads to a high level of technology addiction. Similarly, in the longitudinal 
study conducted by Kraut, Kiesler, and Scherlis (1998), it was concluded that internet and social network use causes loneliness in individuals. Again, in the study conducted by Yavuz (2017) to determine the effect of the frequency of social media use on the loneliness of high school students, it was found that students were isolated from their friendships due to social media use. Türk and Kazan (2019) found a positive relationship between the time allocated to social media and the level of alienation. Including 2089 middle school students between 13 and 16 in his study in Iceland, Ingvadóttir (2014) concluded that students who spend more time on social media become more lonely and alienated.

According to the H20 hypothesis confirmed in the mediation model, it has been concluded that SLEPI has a positive mediation effect in the positive directional effect of SI on alienation. Thus the H20-coded hypothesis contradicts the literature, as it is consistent with the H10 hypothesis. It can be said that the reason is that the analysis is based on a single section design. In future studies, this deficiency can be overcome by using different indexes.

According to the results of SEM analysis, students' social media attitudes, supportive learning environments, and accompanying peer support significantly predict the level of alienation. In other words, the school atmosphere substructures play an important mediating role in the strong relationships between the substructures of the social media attitude scale and alienation. According to these results, it can be said that the level of alienation, which is directly affected by the increase in social media usage needs of students, will decrease thanks to the positive school climate. On the other hand, social media is a phenomenon that is increasingly common in many areas of life, including education. Social media is effective in connecting individuals and masses together, as it includes social interaction, collaboration and negotiation between its users (Bryer \& Zavatarro, 2011, p. 327).

It is claimed that social learning is also effective in the spread of social networks among students. According to the concept of social learning, stimulus that attract students' attention encourage them to learn in the most effective way (Vygotsky, 1978; cited in Chen \& Bryer, 2012). Considering the theory that social learning is integrated with social media technologies (Downes, 2007) in the new digital age, it can be expected that social networks will be used frequently by students. Therefore, understanding how students behave in such networks, how they make friends and being aware of the effects of social networks on them are precious as a potential source of information for educators.

As a result of the research, they conducted in Iran to determine the attitudes of English teachers towards social media tools, Rezaei and Meshkatian (2017) found out that teachers' use of social media tools for teaching with students reinforces outdoor activities, improves the socialization process among students, and positive perceptions about education. The research results reached by Taylor (2020) revealed that students between 13 and 24 are open to the idea of including social media in their academic curriculum and that some already use it as a complementary tool. It has been proven with the researches (Conaway \& Brownson, 2014; Özmen, Aküzüm, Sünkür, \& Baysal, 2011; Toğay, Akdur, 
Yetişken, \& Bilici, 2013) that the inclusion of social media tools in educational processes will provide flexibility in learning and facilitate learning processes.

\section{Implications for Further Research}

It is thought that the awareness of the effects of students' use of social media on their personal lives and friendship relations by school organizations will be effective in creating predictable intervention styles. So, in terms of the life experiences of students through social networks within or outside the school boundaries, school organizations have an important role in choosing among the contents and connecting with existing or new sources of information. As a matter of fact, a sustainable positive school climate includes a process in which students feel socially, emotionally, and physically safe, and students, families, and educators work together and contribute based on a common school vision. In this respect, it is important for teachers, who are an important element of the school climate, to use social media full of technological components for teaching purposes without being unfamiliar with it. It can be said that these uses of teachers will reinforce students' in-school and out-of-school learning, as well as reduce loneliness and alienation in students thanks to positive teacher approaches and peer interactions that will occur during this process.

It could be argued that the biggest challenge for future research will be determining how students with low or no interest in social media can leverage interactivity and social media resources to support learning and teaching.

\section{Recommendations}

Based on the results of the research, the following recommendations are made:

- Studies with larger samples can be conducted on supportive teacher attitudes and the contribution of the positive school environment to alienation.

- In this study, which examines the mediating role of school climate components between social media and alienation, exploratory researches can be conducted on different subjects that may affect alienation in students' daily lives.

- In this study, it was determined that the strongest variable predicting alienation is the sharing need. Studies can be conducted to determine the dynamics of sharing need and their relationships with latent variables that cannot be explained in this study.

- Safe learning environment and peer interaction played a negative mediating role between the need to share and alienation, and between social isolation and alienation. Considering this situation in the regulations to be made in educational institutions will encourage cohesion among students, use of social media for educational purposes and a supportive learning environment. 


\section{Conclusions}

This study aimed to examine the relationships between secondary school students' social media attitudes, social climate perceptions and alienation levels. This study using the SEM approach proved that the need for sharing and social isolation components, which represents social media attitudes, has direct effects on the alienation score. According to this, in cases where the need for social isolation and sharing increases, it can be expected that the level of alienation will increase. In addition, it can be argued that as social isolation increases, the need for safe learning environment and peer communication will increase, and in cases where social competence increases, this need will decrease. According to the findings obtained from the mediation model, it was determined that the effect of social media attitude on the alienation score decreased when the perception of school climate as a mediator variable increased. It seems that the safe learning environment and peer interaction, which are an important component of the school climate, should be considered important by education staff and the use of social media tools to increase in-school interaction should be supported. This study should be completed with further research as it has a single section design and the alienation score may have been affected by different social agents. Experimental designs to be carried out for this purpose will reveal the latent variables that contribute to student alienation.

\section{References}

Ajjan, H., \& Hartshorne, R. (2008). Investigating Faculty Decisions to Adopt Web 2.0 Technologies: Theory and Empirical Tests. Internet and Higher Education, 11(2), 71-80.

Al-Kandari, Y. Y., \& Al-Sejari, M. M. (2020). Social Isolation, Social Support and their Relationship with Smartphone Addiction. Information, Communication \& Society. 23(Apr), 1-19.

Al-Rahmi, W., \& Othman, M. (2013). The Impact of Social Media Use on Academic Performance among University Students: A Pilot Study. Journal of Information Systems Research and Innovation, 4(12), 1-10.

Allen, K.A., Ryan, T., Gray, D. L., McInerney, D. M., \& Waters, L. (2014). Social Media Use and Social Connectedness in Adolescents: The Positives and the Potential Pitfalls. The Australian Educational and Developmental Psychologist, 31(1), 18-31.

Amichai-Hamburger, Y., \& Hayat, Z. (2011). The Impact of the Internet on the Social Lives of Users: A Representative Sample from 13 Countries. Computers in Human Behavior, 27(1), 585-589.

Andreassen, C. S., Pallesen, S., \& Griffiths, M. D. (2017). The Relationship between Addictive Use of Social Media, Narcissism, and Self-Esteem: Findings from a Large National Survey. Addictive Behaviors, 64(Mar), 287-293.

Argon, T., \& Çelik Yılmaz, D. (2016). Lise Öğrencilerinin Akran İlişkileri Algıları ile Okula İlişsin Tutumları Arasındaki İlişki (The Relationship between High School Students' Peer Relations and their Attitude about School). Eğitim ve Öğretim Araştırmaları Dergisi, 25(5), 250-258. 
Arıkan, R. (2004). Araştırma Teknikleri ve Rapor Hazırlama (Research Techniques and Report Preparation). Ankara: Asil Yayınc1lik.

Arıman, F. (2007). İlkögretim 7. ve 8. Sinıf Öğrencilerinin Zorbalı Eğilimleri ile Okul Iklimi Algıları Arasındaki Ilişskinin Incelenmesi (Researching the Relationship between the School Climate and the Bullying Tendency among the $7^{\text {th }}$ and $8^{\text {th }}$ Grade Students in Primary Schools). Unpublished Master's Thesis. Istanbul, Turkey: Yeditepe University.

Atalay, R. (2014). Lise Öğrencilerinin Sosyal Medyaya İlişkin Tutumlart ile Algıladıkları Sosyal Destek Düzeyleri Arasındaki İlişki: Bahçelievler İlçesi Örneği (The Relationship between the Attitudes of High-Schoolers to Social Media and their Levels of Social Support Perceived by them: Example of Bahçelievler District). Unpublished Master's Thesis. Istanbul, Turkey: Marmara University.

Atik, S., \& Özer, N. (2020). The Direct and Indirect Role of School Attitude Alienation to School and School Burnout in the Relation between the Trust in Teacher and Academic Achievements of Students. Education and Science, 45(202), 441-458.

Baker, R. K., \& White, K. M. (2010). Predicting Adolescents' Use of Social Networking Sites from an Extended Theory of Planned Behaviour Perspective. Computers in Human Behavior, 26(6), 1591-1597.

Balc1, A. (2007). Etkili Okul ve Okul Geliştirme: Kuram, Uygulama ve Araştırma (Effective School and School Development: Theory, Practice and Research). Ankara: Pegem Akademi Yayıncilık.

Balçıanlı, C. (2010). The Effects of Social Networking on Pre-Service English Teachers' Metacognitive Awareness and Teaching Practice. Unpublished Doctoral Dissertation. Ankara, Turkey: Gazi University.

Bandura, A. (1997). Self-Efficacy: The Exercise of Control. New York: Freeman.

Bilgin, O., \& Taş, İ. (2018). Ergenlerde Okula Bağlılığın Yordayıcıları Olarak Okul İklimi ve Sosyal Medya Bağımlılığı (School Climate and Social Media Addiction as Predictors of School Engagement among Adolescents). Akdeniz Eğitim Araşstırmaları Dergisi, 12(26), 15-33.

Blum, R. (2005). School Connectedness: Improving the Lives of Students. Baltimore, Maryland: Johns Hopkins Bloomberg School of Public Health.

Boyd, D., \& Ellison, N. B. (2008). Social Network Sites: Definition, History, and Scholarship. Journal of Computer-Mediated Communication, 13(1), 210-230.

Brown, T. A. (2006). Confirmatory Factor Analysis for Applied Research. New York: Guilford.

Bryer, T. A., \& Zavattaro, S. (2011). Social Media and Public Administration: Theoretical Dimensions and Introduction to Symposium. Administrative Theory \& Praxis, 33(3), 325-340.

Bursalıoğlu, Z. (2002). Okul Yönetiminde Yeni Yapı ve Davranış (New Structure and Behavior in School Management). Ankara: Pegem Akademi Yayıncılık.

Byrne, B. M. (2010). Structural Equation Modeling with AMOS: Basic Concepts, Applications and Programming. New York: Routledge.

Çalık, T., \& Kurt, T. (2010). Okul İklimi Ölçeğinin Geliştirilmesi (Development of the School Climate Scale). Eğitim ve Bilim, 157(35), 167-180.

Ceyhan, A., \& Ceyhan, E. (2008). Loneliness, Depression, and Computer Self-Efficacy as Predictors of Problematic Internet Use. Cyber Psychology and Behavior, 11(6), 699701.

Chen, B., \& Bryer, T. (2012). Investigating Instructional Strategies for Using Social Media in Formal and Informal Learning. IRRODL, 1(13), 87-104. 
Çokluk, Ö., Şekercioğlu G., \& Büyüköztürk, Ş. (2018). Sosyal Bilimler İçin Çok Değişkenli Istatistik: SPSS ve LISREL Uygulamalar (Multivariate Statistics for Social Sciences: Applications of SPSS and LISREL). $5^{\text {th }}$ Edition. Ankara: Pegem Akademi Yayınc1lik.

Conaway, W., \& Brownson, S. (2014). Using Multimedia in the Classroom to Enhance Student Retention. In The Clute Institute International Business \& Education Conferences (pp.1671-1676). San Francisco, USA.

Dean, D. G. (1961). Alienation: Its Meaning and Measurement. American Sociological Review, 26(5), 753-758.

Doğan, U., \& Karakuş, Y. (2016). Lise Öğrencilerinin Sosyal Ağ Siteleri Kullanımının Yordayıcısı Olarak Yalnızlık (Multi-Dimensional Loneliness as the Predictor of High School Students' Social Network Sites Use). Sakarya University Journal of Education, $6(1), 57-71$.

Downes, S. (2007). An Introduction to Connective Knowledge. Retrieved from: https:// www.researchgate.net/publication/248290359_An_Introduction_to_Connective_Kno wledge/link/57da852d08ae72d72ea3385f/download. [Accessed 17 May 2019.]

Ellis, T. I. (1988). School Climate. Retrieved from: http://www.eric.ed. gov. [Accessed 17 December 2019.]

Ellison, N., Steinfield, C., \& Lampe, C. (2007). The Benefits of Facebook "Friends": Exploring the Relationship between College Students' Use of Online Social Networks and Social Capital. Journal of Computer-Mediated Communication, 12(3), 11431168.

Finn, J. D. (1989). Withdrawing from School. Review of Educational Research, 2(59), $117-142$.

Frein, S. T., Jones, S. L., \& Gerow, J. E. (2013). When it Comes to Facebook there May Be More to Bad Memory than Just Multitasking. Computers in Human Behavior, 29(6), 2179-2182.

Goel, D., \& Singh, M. (2016). Impact of Students Attitudes towards Social Media Use in Education on their Academic Performance. AIMA Journal of Management \& Research, 2(10), 1-14.

Gürülttii, E., \& Deniz, L. (2017). Lise Öğrencilerinin Akademik Erteleme Davranışları ve Sosyal Medya Kullanımları Arasındaki İlişkilerin İncelenmesi (Investigation of the Relationship between High School Students' Academic Procrastination Behaviors and their Use of Social Media). Journal of Human Sciences, 14(1), 772-788.

Hadjar, A., Backes, S., \& Gysin, S. (2015). School Alienation, Patriarchal Gender-Role Orientations and the Lower Educational Success of Boys: A Mixed-Method Study. Masculinities and Social Change, 4(1), 85-116.

Hatipoğlu, H. B. (2009). Sosyal Medya ve Ticaret Hayatına Etkileri (Social Media and Its Effects on Business Life). CIO Club, 1(2), 71-74.

Hoy, W. K. (2003). School Climate. In J. W. Guhtrie (ed.), Encylopedia of Education (2 ${ }^{\text {nd }}$ Edition, pp. 2121-2124), New York: Thompson Gale.

Hoy, W. K., Tarter, C., \& Kottkamp, R. B. (1991). Open Schools/Healthy Schools: Measuring Organizational Climate. Beverly Hills: SAGE Publications.

Ingvadóttir, A. B. (2014). The Relationship between Facebook Use and Loneliness: A Comparison between High-School Students and University Students. Unpublished Master's Thesis. Reykjavik University, Iceland.

Jacobs, J. E., Lanza, S., Osgood, D.W., Eccles, J. S., \& Wigfield, E. (2002). Changes in Children's Self-Competence and Values: Gender and Domain Differences across Grades One through Twelve. Child Development, 73(2), 509-527.

Johnson, R. A., \& Wichern, R. W. (2007). Applied Multivariate Statistical Analysis. New Jersey: Prentice-Hall. 
Jöreskog, K. G., \& Sörbom, D. (1993). Lisrel 8: Structural Equation Modeling with the SIMPLIS Command Language. Lincolnwood: Scientific Software International, Inc.

Kang, S. (2007). Disembodiment in Online Social Interaction: Impact of Online Chat on Social Support and Psychosocial Well-Being. CyberPsychology \& Behavior, 3(10), 475-478.

Kaplan, A. M., \& Haenlein, M. (2010). Users of the World, Unite! The Challenges and Opportunities of Social Media. Business Horizons, 53(1), 59-68.

Karasar, N. (2005). Bilimsel Araştırma Yöntemi (Scientific Research Method). 14 ${ }^{\text {th }}$ Edition. Ankara: Nobel Akademi Yayıncılık.

Kim, H., Kim, G. J., Park, H. W., \& Rice, R. E. (2007). Configurations of Relationships in Different Media: FtF, Email, Instant Messenger, Mobile Phone and SMS. Journal of Computer-Mediated Communication, 12(4), 1183-1207.

Kline, R. B. (2019). Yapısal Eşitlik Modellemesinin Illkeleri ve Uygulaması (Principles and Application of Structural Equality Modeling). Translated by S. Şen. Ankara: Nobel Akademi Yayıncilik.

Kraut, R. E., Kiesler, S., \& Scherlis, W. L. (1998). Internet Paradox: A Social Technology that Reduces Social Involvement and Psychological Well-Being? American Psychological Association, 9(53), 1017-1031.

Lenhart, A., Purcell, K., Smith, A., \& Zickuhr, K. (2010). Social Media and Mobile Internet Use among Teens and Young Adults. America: Pew Research Center.

Li, C. (2007). How Consumers Use Social Networks. Retrieved from: http://www.eraniu m.at/blog/upload/consumers_socialmedia.pdf. [Accessed 15 December 2019.]

Loukas, A., Suzuki, R., \& Horton, K. D. (2006). Examining School Connectedness as a Mediator of School Climate Effects. Journal of Research on Adolescence, 16(3), 491-502.

Mackey, J. A. (1974). The Dimension of Adolescent Alienation. Unpublished Doctoral Dissertation. Indiana, USA: Indiana University.

Marcin, K., Morinaj, J., \& Hascher, T. (2020). The Relationship between Alienation from Learning and Student Needs in Swiss Primary and Secondary Schools. Zeitschrift für Pädagogische Psychologie, 34(1), 35-49.

McLoughlin, C., \& Lee, M. J. W. (2008). Social Software and Participatory Learning: Pedagogical Choices with Technology Affordances in the Web 2.0 Era. Singapore, Retrieved from: https://pdfs.semanticscholar.org/52ac/3f2b3d75e6de176dce701afc0 b469d7f949a.pdf. [Accessed 1 December 2019.]

Murdock, T. B. (1999). The Social Context of Risk: Status and Motivational Predictors of Alienation in Middle School. Journal of Educational Psychology, 91(1), 62-75.

Mutlu, Ş. (2014). Lise Öğrencilerinin Facebook Kullanımı-Uygulamalarınin Özsaygl ve Yalnızlık Düzeyleri ile İlişkisinin İncelenmesi: Erciş İlçesi Örneği (Examining the Relationship between High School Students' Facebook Use and their Applications with Self-Esteem and Loneliness Levels: Example of Erciş District). Unpublished Master's Thesis. Van, Turkey: Yüzüncüyıl University.

Omay, H. (2008). İlköğretim Okulu Öğrencilerinin Okul İklimi Alglları ile Saldırganlık Ölçeği Puanlar Arasındaki İlişkinin İncelenmesi (Relations between School Environmental Perception and Aggressiveness Scale Points of Students in Elementary Schools). Unpublished Master's Thesis. Istanbul, Turkey: Yeditepe University. 
Otrar, M., \& Argın, F. S. (2015). Öğrencilerin Sosyal Medyaya İlişkin Tutumlarını Belirlemeye Yönelik Bir Ölçek Geliştirme Çalışması (A Scale Development Study to Determine the Attitude of Students' towards Social Media). Ĕgitim ve Ögretim Araştırmaları Dergisi, 4(1), 391-403.

Özdamar, K. (2016). Eğitim, Sağllk ve Davranış Bilimlerinde Ölçek ve Test Geliştirme: Yapısal Eşitlik Modellemesi (Scale and Test Development in Education, Health and Behavioral Sciences: Structural Equation Modeling). Eskişehir: Nisan Kitabevi.

Özmen, F., Aküzüm, C., Sünkür, M., \& Baysal, N. (2011). Sosyal Ağ Sitelerinin Eğitsel Ortamlardaki İşlevselliği (Functionality of Social Networking Sites in Educational Environments). In $6^{\text {th }}$ International Advanced Technologies Symposium (IATS'11) (pp. 42-47). Firat University, Turkey.

Öztürk, M. F., \& Talas, M. (2015). Sosyal Medya ve Eğitim Etkileşimi (Interaction of Social Media and Education). Journal of World of Turks, 1(7), 101-120.

Polat, Ş. (2018). Ortaokul Öğrencilerinde Okula Yabancılaşma ve Okul Tükenmişliği İlişkisinin İncelenmesi (Examination of the Relationship between School Alienation and School Burnout among Secondary School Students). Uludağ Üniversitesi Eğitim Fakültesi Dergisi, 31(1), 257-277.

Preacher, K. J., \& Hayes, A. F. (2004). SPSS and SAS Procedures for Estimating Indirect Effects in Simple Mediation Models. Behavior Research Methods, Instruments \& Computers, 36(4), 717-731.

Preacher, K. J., \& Hayes, A. F. (2008). Asymptotic and Resampling Strategies for Assessing and Comparing Indirect Effects in Multiple Mediator Models. Behavior Research Methods, 40(3), 879-891.

Rezaei, S., \& Meshkatian, M. A. (2017). Iranian Teachers' Attitude towards Using Social Media and Technology to Increase Interaction amongst Students Inside or Outside the Classroom. Theory and Practice in Language Studies, 7(6), 419-426.

Russell, C. (1994). School Practices that Prevent and Contribute to Alienating Students from School. Unpublished Doctoral Dissertation. Austin, USA: The University of Texas.

Ryan, R. (2007). The Effects of Web-Based Social Networks on Student Achievement and Perception of Collaboration at the Middle School Level. Unpublished Doctoral Dissertation. California, USA: Touro University.

Safipour, J., Tessma, M. K., Higginbottom, G., \& Emami, A. (2010). Measuring Social Alienation in Adolescence: Translation and Validation of the Jessor and Jessor Social Alienation Scale. Scandinavian Journal of Psychology, 51(6), 517-524.

Sağlik (2014). Korkunç Gerçek! Twitter ve Facebook Sağ Beyni Bitiriyor. (Stubborn! Between Twitter and Facebook). Star. Retrieved from: https://www.star.com.tr/saglik /twitter-ve-facebook-sag-beyni-bitiriyor-haber-829108/. [Accessed 13 October 2019.]

Samdal, O., Nutbeam, D., Wold, B., \& Kannas, L. (1998). Achieving Health and Educational Goals Through Schools: A Study of the Importance of the School Climate and the Students' Satisfaction with School. Health Education Research, 3(13), 383397.

Sanberk, İ. (2003). Öğrenci Yabancılaşma Ölçeği: Bir Geçerlik ve Güvenirlik Çalışması (Student Alienation Scale: A Validity and Reliability Study). Unpublished Master's Thesis. Adana, Turkey: Çukurova University.

Sappington, L. (2020). Through the Screen: Examining Peer Relationships, Social Anxiety, Loneliness, and Social Media in Undergraduates. Honors Thesis. Mississippi, USA: University of Mississippi.

Savcı, M., \& Aysan, F. (2018). Kişilerarası Yetkinlik, Yalnızlık, Olumsuz Değerlendirilme Korkusu, Ödül ve Cezanın Sosyal Medya Bağımlılığını Yordama ve Sosyal Medya Kullanan-Kullanmayan Ergenleri Doğru Sinıflandırma Düzeyi (Interpersonal 
Competence, Loneliness, Fear of Being Negatively Evaluated, the Level of Reward and Punishment to Interpret Social Media Addiction and Correct Classification of Adolescents Who Use and Do Not Use Social Media). Addicta: The Turkish Journal on Addictions, 5(3), 1-41.

Schulz, L., \& Rubel, D. (2011). A Phenomenology of Alienation in High School: The Experiences of Five Male Non-Completers. Professional School Counseling, 14(5), 286-298.

Schumacker, R. E., \& Lomax, R. G. (2010). A Beginner's Guide to Structural Equation Modeling. New York: Routledge.

Seeman, M. (1959). On the Personal Consequences of Alienation in Work. American Sociological Review, 32(2), 273-285.

Sidorkin, A. M. (2004). In the Event of Learning: Alienation and Participative Thinking in Education. Educational Theory, 54(3), 251-262.

Tabachnick, B. G., \& Fidell, L. S. (2015) Çok Değişkenli İstatistiklerin Kullanımı (Use of Multivariate Statistics). Translated by M. Baloğlu. Ankara: Nobel Akademi Yayınc1lk.

Taylor, K. (2020). How Does Social Media Use Impact Students' Addiction, Interpersonal Skills, and Well-Being? Unpublished Doctoral Dissertation. San Diego, USA: Northcentral University.

Tezcan, M. (1997). Eğitim Sosyolojisi (Sociology of Education). Ankara: Anı Yayıncıllk.

Thapa, A., \& Cohen, J. (2013). A Review of School Climate Research. Review of Educational Research, 3(83), 357-385.

Toğay, A., Akdur, T. E., Yetişken, İ. C., \& Bilici, A. (2013). Eğitim Süreçlerinde Sosyal Ağların Kullanımı: Bir MYO Deneyimi (The Usage of Social Networks in Education Processes: A Vocational High School Experience). In Akademik Bilişim Konferansı Bildirileri II, 23 (pp. 1006-1011). Antalya, Turkey: Akdeniz University.

Toprak, A., Yıldırım, A., Aygül, E., \& Binark, M. (2009). Toplumsal Paylaşım A $\breve{g} ı$ Facebook: Görülüyorum Öyleyse Varrm (Social Network Facebook: I'm Seen So I'm in). Ankara: Kalkedon Yayınları.

Tosun, B. N. (2010). Illetişim Temelli Marka Yönetimi (Communication-Based Brand Management). İstanbul: BetaYayınları.

Türk, A. R., \& Kazan, H. (2019). Lise Öğrencilerinin Sosyal Medya Kullanım Tutumları ile Yabancılaşma Arasındaki İlişkinin İncelenmesi: İstanbul İli Eyüpsultan İlçesi Örneği (Investigation of the Relationship between High School Students'Social Media Attitudes and Alienation: Example of Eyüpsultan District of Istanbul). Sosyal Bilimler Dergisi, 37, 450-484.

Türkel, Z., \& Dilmaç, B. (2019). Ergenlerde Sosyal Medya Kullanımı, Yalnızlık ve Yaşam Doyumu Arasındaki Yordayıc İlişkiler (The Relationship Relations between Social Media Use in Adolescents, Loneliness and Life Satisfaction). Necmettin Erbakan Üniversitesi Ereğli Ĕ̈itim Fakültesi Dergisi, 1(1), 57-70.

Valdez, G. (2002). Critical Issue: Technology: A Catalyst for Teaching and Learning in the Classroom. Retrieved from: https://pdfs.semanticscholar.org/ b136/6cff7219026 ef13c1164cf42ee2db82105f2.pdf. [Accessed 1 December 2019.]

Van-Cleemput, K. (2010). I'll See You on IM, Text, or Call You: A Social Network Approach of Adolescents' Use of Communication Media. Bulletin of Science, Technology \& Society, 30(2), 75-85.

Welsh, W. N. (2000). The Effects of School Climate on School Disorder. The Annals of the American Academy of Political and Social Science, 567(1), 88-107.

Yavuz, Y. (2017). Lise Öğrencilerinin Sosyal Medya Kullanma Sikliğının Yalnızlı Algilarina Etkisi (Effect of High School Students' Frequency of Using Social Media 
on their Perception of Loneliness). Unpublished Master's Thesis. Istanbul, Turkey: Haliç University.

Yazıcıoğlu, Y., \& Erdoğan, S. (2004). Spss Uygulamalı Bilimsel Araştırma Yöntemleri (Spss Applied Scientific Research Methods). Ankara: Detay Yayınc1lı.

Young, K., Pistner, M., O'mara, J., \& Buchanan, J. (1999). Cyber Disorders: The Mental Health Concern for the New Millennium. CyberPsychology \& Behavior, 2(5), 475479 .

\section{Appendix 1. Structural Equation Model}

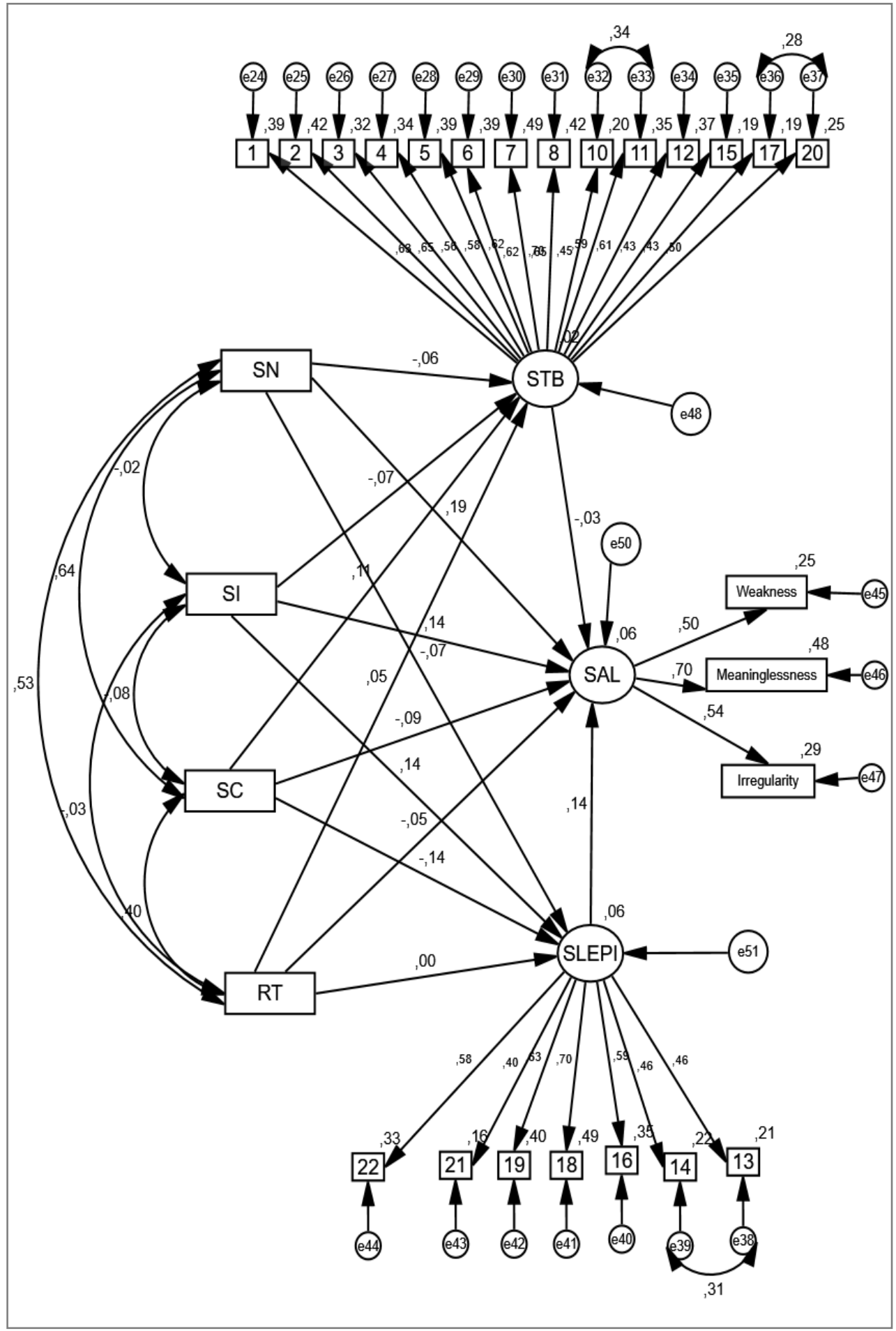

